\title{
Analisis Residu Tetrasiklin pada Hati Ayam Potong di Kota Kendari
}

\author{
Yamin Yaddi $^{\text {* }}$, Abdul Rizal1, Fitrianingsih ${ }^{1}$, Restu Libriani' ${ }^{1}$, Deki Zulkarnain ${ }^{1}$ \\ ${ }^{1}$ Fakultas Peternakan Universitas Halu Oleo, Kendari \\ Kampus Hijau Bumi Tridharama, Jl. H.E.A. Mokodompit, Kambu, Kendari \\ *Email korespondensi: yaminyaddi@gmail.com
}

(Diterima: 12-11-2018; disetujui 15-12-2019)

\begin{abstract}
ABSTRAK
Penelitian ini bertujuan untuk menganalisis dan menentukan keberadaan serta tingkat residu antibiotik terutama golongan tertasiklin pada sampel lapang hati ayam broiler yang berada di Kota Kendari. Metode yang digunakan meliputi observasi lapang, pengambilan sampel dan pengujian sampel di laboratorium. Penentuan lokasi pengambilan sampel secara purposive sampling. Lokasi sampling (pasar) yang dijadikan sebagai tempat pengambilan sebanyak 5 (lima) pasar sesuai dengan kriteria yang telah ditentukan. Jenis sampel yang digunakan adalah hati ayam potong yang berasal dari beberapa pedagang dengan kisaran bobot karkas/bobot hati yang berbeda. Pengambilan sampel hati dilakukan dengan metode simple random sampling. Pengujian sampel digunakan sesuai dengan Standar Nasional Indonesia dengan metode Tapis. Pengujian residu dilakukan melalui uji skrining test. Hasil penelitian menunjukkan pemeriksaan residu antibiotik pada semua sampel adalah negatif. Kesimpulannya adalah produk peternakan dari ayam potong yang di pasarkan di Kota Kendari sebagian besar tidak mengandung residu antibiotik. Peternak ayam potong yang ada di Kota Kendari sudah mulai bijak dalam penggunaan antibiotik serta penentuan waktu panen.
\end{abstract}

Kata kunci: ayam broiler, hati ayam, residu antibitik

\begin{abstract}
This study aimed to analyze and determine the presence and level of antibiotic residue, especially tetracycline group in broiler chicken liver in Kendari. The methods used in this study were field observations, sampling, and laboratory testing. Determination of sampling location was done by purposive sampling. The sampling location (market) chosen for this study were 5 (five) markets based on predetermined criteria. The type of sample collected was broiler liver from several butchers with different ranges of carcass / liver weight. Liver sampling was done using simple random sampling method. The sample was tested using Tapis method in accordance to Indonesian National Standard (SNI). Tetracycline residue was tested by screening test. The results showed negative antibiotic residues in all samples. It can be concluded that livestock products from broiler chicken in Kendari market are mostly free from antibiotic residue. It can be assumed that the broiler farmers in Kendari have become wise in using antibiotics and the determination of harvest after antibiotic treatment.
\end{abstract}

Keywords: antibiotic residues, broilers liver, broiler meat

\section{PENDAHULUAN}

Penyediaan pangan asal hewan yang aman, sehat, utuh dan halal merupakan tanggung jawab pemerintah dan pelaku usaha bidang peternakan. Dewasa ini, keamanan pangan terutama terhadap bahaya residu antimikroba dan cemaran bilogis serta kimia menjadi sorotan utama. Produk perunggasan sebagai salah satu sumber pangan asal hewan yang banyak ditemukan residu antibiotik baik yang disebabkan oleh pakan yang mengandung 
antibiotik (golongan tetrasiklin) maupun residu yang ditimbulkan akibat pola medikasi saat pemeliharaan yang tidak efektif. Rusiana dan Iswarawanti (2004) melaporkan bahwa 85\% daging dan $37 \%$ hati ayam broiler yang diperjual belikan di sejumlah pasar di kawasan Jabotabek mengandung residu antibiotik tilosin, penisilin, oksitetrasiklin, dan kanamisin dengan residu dari kelompok penisilin yang paling banyak dijumpai. Pada penelitian lain, Purwaningtyas dan Cahyaningtiyas (2004) melaporkan adanya residu antibiotik kloramfenikol pada hati dan ginjal ayam petelur afkir yang dipasarkan di Kecamatan Kota Kabupaten Ponorogo. Sri et al. (2016) menambahkan bahwa terdapat residu antibiotik golongan tetrasiklin pada hati, daging paha dan telur di beberapa wilayah di Indonesia.

Paparan residu antibiotik pada produk peternakan dapat menyebabkan gangguan kesehatan bagi manusia. Resistensi antibiotik pada manusia yang mengkonsumsi daging yang berasal dari ternak yang mengonsumsi antibiotik secara tidak terkontrol, akan bersifat tidak nyata, residu antibiotik dapat mengakibatkan timbulnya alergi dan resistensi terhadapantibiotik jika terakumulasi atau bahkan menyebabkan hipersensitivitas terhadap stimulan, yang pada akhirnya dapat bersifat karsinogenik, mutagenik, dan keracunan (Voogd, 1981; Sundlof dan Cooper, 1996; dan Follet, 2000).

Populasi ternak unggas di Kota kendari terus mengalami kenaikan setiap tahunnya termasuk produk olahannya. Proyeksi BPS (2016) melaporkan bahwa rata-rata kenaikan pertahun dalam lima tahun terakhir, jumlah ternak ayam pedaging yang dipotong di Kota Kendari Mencapai 48,15\%. Angka tersebut terbilang cukup besar daerah pesisir. Potensi residu antibiotik pada daging ayam potong yang ada di Kota Kendari sangat mungkin untu terjadi. Amiluddin et al. (2017) melaporkan bahwa residu antibiotik golongan tetrasiklin pada daging ayam potong pada beberapa pasar di Kota Kendari menunjukan hasil yang negatif. Saniwanti et al. (2015) juga melaporkan keberadaan residu antibiotik pada daging ayam potong. Pada penelitian tersebut, ditemukan adanya residu antibiotik golongan tetrasiklin di daging pada beberapa pasar yang ada di Kota Kendari namun masih dalam ambang batas dan layak dikonsumsi. Dari beberapa penelitian yang dilakukan di Kota Kendari tentang keberadaan residu antibiotik terutama golongan tetrasiklin dipandang masih sangat perlu demi menjamin keamanan pangan asal hewan terutama yang berasal dari hewan.

\section{METODE PENELITIAN}

Metode yang digunakan dalam penelitian ini meliputi observasi lapang, pengambilan sampel dan pengujian sampel di laboratorium. Penentuan lokasi pengambilan sampel hati ayam potong dilakukan secara purposive sampling. Lokasi sampling (pasar) yang dijadikan sebagai tempat pengambilan sebanyak 5 (lima pasar) sesui dengan criteria.

Jenis sampel yang digunakan dalam pelaksanaan kegiatan penelitian ini adalah sampel pasar. Sampel yang diperoleh diharapkan dapat mewakili kondisi wilayah sampel. Jenis sampel yang digunakan adalah hati ayam potong yang berasal dari beberapa peternak dengan kisaran bobot karkas/bobot hati yang berbeda. Pengambilan sampel hati dilakukan dengan metode simple random sampling. Sampel hati mewakili pasar sebanyak 3 sampel yang kemudian dijadikan 1 untuk mewakili lokasi sampel/pasar.

Pengujian sampel digunakan sesuai dengan Standar Nasional Indonesia dengan metode Tapis. Pengujian residu dilakukan melalui uji skrining test. Pada uji skrining digunakan kuman uji yang spesifik untuk golongan antibiotika tetrasiklin yaitu spora Bacillus cereus ATCC. Sebanyak $1 \mathrm{ml}$ biakan kuman uji dicampur dengan $100 \mathrm{ml}$ media yang telah dicairkan. Selanjutnya dipipet $8 \mathrm{ml}$ media yang telah mengandung kuman uji atau spora dan dimasukkan ke dalam cawan dan dilakukan ulangan triplo. Larutan sampel yang sudah dihomogenkan diambil $75 \mu$ l lalu diteteskan pada kertas cakram, kemudian dimasukkan kedalam media. Larutan baku pembanding diteteskan sebagai kontrol positif. Selanjutnya cawan tersebut diinkubasi selama 16 jam-18 jam pada temperatur $30^{\circ} \mathrm{C} \pm 1^{\circ} \mathrm{C}$,

Sampel ditimbang $5 \mathrm{~g}$ dihomogenkan lalu ditambah $2 \mathrm{ml}$ TCA $20 \%$ dan $15 \mathrm{ml}$ dapar Mcllvaine. Selanjutnya dikocok dan sentrifugasi selama 10 menit pada kecepatan $4000 \mathrm{rpm}$. Tahapan tersebut diulangi pada endapan hasil sentrifugasi. Supernatan yang diperoleh dimasukkan dalam mini kolom C-18 yang telah diaktifasi lalu dialirkan $3 \mathrm{ml}$ metanol 
$5 \%$ dan $3 \mathrm{ml}$ methanol p.a.Eluet yang diperoleh dievaporasi, ditambah larutan fase gerak dan disaring. Larutan diinjeksikan ke dalam HPLC dengan kondisi kecepatan alir $1.2 \mathrm{ml} / \mathrm{menit}$, kolom C-18, detektor UV-Vis $365 \mathrm{~nm}$ dan menggunakan fase gerak berupa asam oksalat 0,01 M dan campuran ACN-metanol (70:30).

\section{HASIL}

Berdasarkan uji kuantitatif diporoleh hasil. Berdasarkan hasil pengujian laboratorium terhadap keberadaan residu antibiotik golongan tetrasiklin pada hati ayam potong tersaji pada Tabel 1. Uji Kualitatif terhadap sampel hati ayam potong menunjukan hasil Negatif.

Tabel 1. Hasil Pemeriksaan residu antibiotik pada hati ayam potong yang dipasarkan di Kota Kendari.

\begin{tabular}{|c|c|c|c|c|c|}
\hline No & & & $\begin{array}{c}\text { Bobot } \\
\text { Karkas }(\mathrm{Kg})\end{array}$ & Jenis Sampel & Hasil \\
\hline \multirow{3}{*}{1} & \multirow{3}{*}{ PBR } & 1 & 1,83 & Hati & Negatif \\
\hline & & 2 & 1,85 & Hati & Negatif \\
\hline & & 3 & 1,72 & Hati & Negatif \\
\hline \multirow{3}{*}{2} & \multirow{3}{*}{ PKR } & 1 & 0,72 & Hati & Negatif \\
\hline & & 2 & 0,65 & Hati & Negatif \\
\hline & & 3 & 0,61 & Hati & Negatif \\
\hline \multirow{3}{*}{3} & \multirow{3}{*}{ PKT } & 1 & 1,82 & Hati & Negatif \\
\hline & & 2 & 1,87 & Hati & Negatif \\
\hline & & 3 & 1,78 & Hati & Negatif \\
\hline \multirow{3}{*}{4} & \multirow{3}{*}{ PAD } & 1 & 0,76 & Hati & Negatif \\
\hline & & 2 & 0,88 & Hati & Negatif \\
\hline & & 3 & 0,66 & Hati & Negatif \\
\hline \multirow{3}{*}{5} & \multirow{3}{*}{ PSL } & 1 & 1,97 & Hati & Negatif \\
\hline & & 2 & 2,22 & Hati & Negatif \\
\hline & & 3 & 2,19 & Hati & Negatif \\
\hline
\end{tabular}

Keterangan: PBR: Pasar Baruga, PKR: Pasar Korem, PKT: Pasar Kota, PAD: Pasar Andounohu, PSL: Pasar Lapuplu.

Kondisi ini menunjukkan bahwa pada hati ayam potong yang dijadikan sampel tidak mengandung residu antibiotk golongan tetrasiklin. Hasil negatif pada sampel memberi gambaran kondisi lapangan tentang manajemen pemeliharaan yang berhubungan dengan kebijaksanaan peternak dalam menggunakan antibiotik dan penentuan waktu panen. Martaleni (2007) menjelasakan bahwa keberadaan residu antibiotik pada produk peternakan berasal dari pemberian antibiotik dalam skala besar melalui air minum yang diikuti oleh pemberian antibiotik melaui pakan.

Kemungkinan lain adalah hati ayam potong yang digunakan sebagai sampel berasal dari peternakan tanpa kasus penyakit yang disebabkan oleh bakteri sehingga tidak dilakukan pengobatan. Kemungkinan lain yang mungkin terjadi adalah peternak telah meiliki pemahaman tetang masa henti pemberian antibiotik sebelum ternak dipanen. Masa henti tetrasiklin adalah 5 hari setelah penggunaan terakhir saat program pengobatan atau pencegahan penyakit.

Masa henti antibiotik yang digunakan merupakan informasi penting yang harus dipahami oleh peternak dalam upaya penjaminan dan penyediaan daging ayam potong yang berkualitas. Andy et al. (2016) menyebutkan bahwa penggunaan antibiotik yang tidak sesuai dengan aturan/dosis dapat menyebabkan terjadinya residu antibiotik pada prodak ternak tersebut. Dalam penggunaan antibiotik pada ternak, Kusumaningsih et al. (1996) menjelasakan bahwa pemakaian antibiotik dalam bidang peternakan perludiperhatikan waktu hentinya yaitu jarak antara pemberian antibiotik terakhir sampai dengan produk ternak tersebut (telur, daging dan susu) boleh dikonsumsi manusia.

Penggunaan antibiotik dengan tujuan pencegahan biasanya dilakukan pada saat ternak berumur 17 hari. Pada umur tersebut, paparan amoniak yang berasal dari feses/kotoran ayam potong mulai menumpuk sehinga menyebabkan terjadi iritasi pada saluran pernapasan (sinus orbitalis, laring dan trachea) sehingga bakteri sangat mudah untuk menginfeksi. Untuk menanggulangi dan mencegah kejadian tersebut, peternak biasanya mulai menggunakan antibiotik sebagai upaya preventif. Salah satu jenis 
antibiotik yang banyak digunakan adalah golongan tetrasiklin (oksitetrasil, doksisiklin dan klortetrasilin) yang diberikan secara peroral melalui air minum. Penggunaan antibiotik dapat berlangsung hingga 3-5 hari sampai dengan umur ayam 21 hari. Prescott dan Baggot (1993) menjelaskan bahwa waktu henti antibiotik golongan tetrasiklin cukup panjang yang disebabkan oleh sirkulasi dan enterohepatik yang ekstensif. Hasil yang diperoleh pada penelitian ini menunjukan tidak terditeksinya antibiotik golongan tetrasiklin pada daging ayam potong. Hal ini sangat dipengaruhi oleh tingkat kejadian penyakit dan langkan penanganan serta pemahaman peternak dalam penggunaan antibiotik dalam prosen pemeliharaan.

\section{KESIMPULAN}

Produk peternakan dari ayam potong yang di pasarkan di Kota Kendari sebagian besar tidak mengandung residu antibiotik. Peternak ayam potong yang ada di Kota Kendari sudah mulai bijak dalam penggunaan antibiotik serta penentuan waktu panen. Populasi ayam potong yang masih sangat rendah dapat menjadi salah satu penyebab minimnya transmisi serta tingkat kejadian penyakit pada ayam potong sehingga penggunaan antibiotik sangat kurang. Pengawasan terhadap produk asal hewan harus menjadi aktifitas rutin pemerintah daerah dalam upaya menjamin keselamatan konsumen terhadap bahaya biologis dan kimia yang mungkin ditimbulkan. Sosialisasi dan edukasi terhadap peternakan juga dapat menjadi upaya alternative dalam upaya menjamin kualitas dan mutu pangan asal hewan, terutama produk perunggasan (daging, susu dan telur).

\section{DAFTAR PUSTAKA}

Amiluddin I, N.S. Asminaya, \& Y. Yaddi. 2017. Pengkajian residu antibiotik Golongan tetrasiklin pada daging ayam potong di Kota Kendari. Seminar Nasional V Fakultas Kedokteran Hewan Universitas Nusa Cendana. Kupang 20 September 2017.

Andy, L. Agustina, \& A Mujinisa. 2016. Waktu Henti Antibiotika Zinc Bacitracin Terhadap Residunya pada Broiller. JITP 4(3):112-118.

BPS. 2016. Kota Kendari dalam Angka. Badan Pusat Statistik. Kendari.
Follet G. 2000. Antibiotik Resistance in the Europian Union-Science, Politics and Policy. AgBio Forum 3(2-3):148-155.

Kusumaningsih A., T.B. Murdiati, \& S. Bahri. 1996. Pengetahuan Peternak tentang Waktu Henti Obat dan Hubungannya dengan Residu Antibiotika pada Usus. Media Kedokteran Hewan 12:260-267.

Martaleni. 2007. Deteksi Residu Antibiotik pada Karkas, Organ dan Kaki Ayam Pedaging yang diperoleh dari Pasar Tradisional Kabupaten Tangerang. Tesis. Program Pascasarjana, Institut Pertanian Bogor. Bogor.

Presott J.F. \& J.D. Baggot. 1993. Tetracyclines. In: Prescott J.F., J.D. Baggot (eds), Antimicrobial Therapy in Veterinary Medicine, $2^{\text {nd }}$ ed. Lowa State University Press. Lowa. pp. 215-228.

Purwaningtyas L. \& N. Cahyaningtiyas. 2004. Residu Antibiotik pada Hati dan Ginjal Ayam Petelur Afkir. Republika. Jumat, 10 Desember 2004.

Rusiana \& D.N, Iswarawanti. 2004. 85\% Daging Ayam Broiler Mengandung Antibiotik. Tabloid Senior No.236/Edisi 23, 29 Januari 2004.

Saniwanti, Nuraeni, \& D. Agustina. 2015. Studi Residu Antibiotik Daging Broiler Yang Beredar di Pasar Tradisional Kota Kendari. JITRO 2(2):30-38.

Sri W., U. Patriana, N. Ariyani, Ambarwati, \& E. Nugraha. 2016. Pengkajian Residu Tetrasiklin dalam Paha, Hati dan Telur Ayam pada Beberapa Provinsi di Indonesia. Balai Besar Pengujian Mutu dan Sertifikasi Obat Hewan. Bogor.

Sundlof, S.F. \& J. Cooper. 1996. Human Health Risks Associated with Drug Residues in Animal-Derived Foods. In W.A. Moats and M.B. Medina (Eds). 1996. Veterinary Drug Residues: Food Safety. American Chemical Society Symposium Series 636:5-17.

Voogd, C.E. 1981. On the mutagenicity of nitroimidazoles. Mutat. Res. 86(3):243277. 